\title{
KUALITAS PELAYANAN KANTOR PERTANAHAN DALAM PELAKSANAAN PENDAFTARAN TANAH UNTUK PERTAMA KALI SECARA SPORADIK DI KOTA BATAM
}

\section{THE QUALITY OF SERVICE OF LAND AGENCY IN THE IMPLEMENTATION OF FIRST LAND REGISTRATION SPORADICALLY OF BATAM CITY}

\author{
Meri Enita Puspita Sari \\ Program Studi Ilmu Pemerintahan, Universitas Riau Kepulauan, \\ Batam, Indonesia \\ puspita.meri@yahoo.co.id
}

\begin{abstract}
Abstrak
Pendaftaran tanah untuk pertama kalinya dapat dilakukan secara sporadik adalah bagian pertama pendaftaran tanah yang dilakukan atas permintaan pihak yang berkepentingan, mengenai satu atau beberapa objek pendaftaran tanah di dalam wilayah atau bagian dari desa / kelurahan secara individu atau berkelompok. Dinas Pertanahan Batam bertugas untuk melakukan layanan pendaftaran tanah yang dikelola oleh Kantor Pertanahan sendiri. Selain tugas lain yang ditugaskan oleh Menteri Agraria, hal ini sesuai dengan Keputusan Menteri Tenaga Kerja Pendayagunaan Aparatur Negara Nomor 63 Tahun 2003 sebagai berikut: pelayanan publik adalah kegiatan pelayanan yang dilakukan oleh penyelenggara pelayanan publik sebagai upaya. untuk memenuhi kebutuhan penerima layanan serta pelaksanaan ketentuan undangan undang-undang. Hasil penelitian menunjukkan bahwa Kualitas Layanan Kantor Pertanahan dalam Pelaksanaan Pendaftaran Tanah Pertama secara sporadik dalam memberikan layanan pendaftaran tanah kepada pemohon atau masyarakat sudah berjalan dengan baik meski masih ada beberapa pegawai yang belum maksimal dalam memberikan pelayanan sehingga bias mempengaruhi pelayanan, Kurangnya sarana dan prasarana yang ada di Kantor Pertanggu Kota Batam.
\end{abstract}

Kata Kunci: Kualitas, Pelayanan, Tanah, Sporadik

\begin{abstract}
Registration of land for the first time can be done by sporadic is the first part of land registration done at the request of the interested parties, concerning one or several objects of land registration within the territory or part of a village / kelurahan individually or massively.Batam Land Office has duty to carry out land registration service which managed by Land Office itself. As well as other tasks assigned by the Minister of Agrarian Affairs, this is in line with the Decision of Minister of Defense Apparatus State Apparatus Number 63 Year 2003 as follows: public service is any service activities undertaken by the providers of public services as an effort to meet the needs of service recipients as well as the implementation of the provisions of legislation invitation.The result of the research shows that the Quality of Land Office Service in the Implementation of First Land Registration Sporadically in giving the land registration service to the applicant or the community, has been running properly although there are still some employees still not maximally in providing services so that the bias affects the service, Lack of facilities and infrastructure facilities that exist in Batam City Pertanahan Office.
\end{abstract}

Keywords: quality, service, land, sporadic. 


\section{PENDAHULUAN}

Kualitas pelayanan pada dasarnya memberikan persepsi secara konkrit mengenai kualitas suatu layanan. Konsep kualitas layanan ini merupakan suatu revolusi secara menyeluruh, permanen dalam mengubah cara pandang manusia dalam menjalankan atau mengupayakan usaha-usahanya yang berkaitan dengan proses dinamis, berlangsung, terus menerus di dalam memenuhi harapan, keinginan dan kebutuhan. Menurut Rambat Lupiyoadi dan A. Hamdanike untungan eksternal yang dimaksud dapat diimplikasikan dalam proses produksi suatu barang (jasa), yaitu di mana kualitas produk (jasa) yang diberikan oleh perusahaan dapat menciptakan suatu persepsi positif dari pelanggan terhadap perusahaan dan menghasilkan suatu kepuasan serta loyalitas pelanggan. Sementara itu, yang dimaksud dengan keuntungan internal tampak pada saat bersamaan dengan diperolehnya keuntungan eksternal, dimana fokus perusahaan pada kualitas dapat membawa nilai positif internal perusahaan dalam proses peningkatan (misalnya, peningkatan desain produk dan kontrol material, penggunaan bahan baku yang efisien, pengurangan kegiatan reproduksi, dan sebagainya) (Lupiyoadi dan Hamdani, 2016).

Hak atas tanah adalah hak yang di berikan kepada seseorang atau badan hukum yang meliputi atas permukaan bumi saja. Sedangkan hak mepergunakan tanah adalah hak yang diberikan oleh Negara kepada badan hukum Indonesia untuk dapat melakukan eksplorasi, eksploitas, dan penelitian, untuk mengambil manfaat ekonomi dan manfaat-manfaat lainnya dari alam Indonesia, yang bertujuan untuk kepentingan ekonomi yang pada akhirnya baik langsung ataupun tidak langsung akan menyejahterakan rakyat dan demi mewujudkan kemakmuran secara nasional, yang wilayah haknya meliputi tanah, tubuh bumi, dan ruang angkasa (pasal 4 ayat (2) Undang-Undang Pokok Agraria).

Kewajiban untuk menyelenggarakan pendaftaran tanah bagi Pemerintah di seluruh wilayah Republik Indonesia di atur dalam pasal 19 Undang-Undang Pokok Agraria, yaitu:1). Untuk menjamin kepastian hukum oleh Pemerintah, diadaka pendaftaran tanah di seluruh Wilayah Republik Indonesia menurut ketentuan-katentuan yang diatur dengan Peraturan pemerintah. 2). Pendaftaran tersebut dalam ayat 1 pasal ini meliputi: (a) Pengukuran, perpetaan dan pembukaan, (b) Pendaftaran hak-hak tanah dan peralihan hak-hak tersebut, (c) Pemberian surat-surat tanda bukti hak, yang berlaku sebagai alat pembuktian yang kuat. 3). Pendaftaran tanah di selenggarakan dalam mengingat keadaan Negara dan masyarakat, 
keperluan lalu lintas social-ekonomi serta kemungkinan penyelenggaraannya, menurut pertimbangan menteri Agraria . 4) Dalam peraturan pemerintah di atur biaya-biaya yang bersangkutan dengan pendaftaran termaksud dalam ayat 1 di atas, dengan ketentuan bahwa rakyat tidak mampu dibebaskan pembayaran biaya-biaya tersebut.

Undang-undang juga telah mengatur dengan kewajiban pemegang hak milik, pemegang hak guna bangunan. Pemegang hak guna usaha, untuk pendaftaran hak atas tanahnya. Kewajiban bagi pemegang hak milik atas tanah untuk mendaftarkan tanahnya ditur dala Pasal 23 ayat 1 dan 2 Undang-Undang Pokok Agraria. Kewajiban pemegang hak guna usaha untuk mendaftarkan tanahnya di atur dalam pasal 32 ayat 1 dan 2 Undang-Undang Pokok Agraria.Sedangkan kewajiban pemegang hak guna bagunan untuk mendaftarkan tanahnya diatur pasal 38 ayat 1 dan 2 Undang-Undang Pokok Agraria (Sahnan, 2016). UndangUndang Pokok Agraria telah mengatur mengenai mengenai kewajiban pemegang hak pakai atas tanah untuk didaftarkan.Pendaftaran tanah dapat dilakukan dengan secara sporadik. Dasar hukum pendaftaran tanah secara sporadik adalah: (a)Pasal 1 angka 11 Peraturan Pemerintah Nomor 24 Tahun 1997 tentang Pendaftaran Tanah. (b)Pasal 13 sampai dengan Pasal 32 Peraturan Pemerintah Nomor 24 Tahun 1997.(c)Pasal 73 sampai dengan Pasal 93 Permen Agraria/Kepala BPN Nomor 3 Tahun 1997 (Sahnan, 2016).

Pasal 1 PP Nomor 10 tahun 1961 hanya menyebutkan bahwa pendaftaran tanah diselenggarakan oleh jawatan tanah. Sedangkan di dalam PP Nomor 21 Tahun 1997, secara tegas menyebutkan bahwa instansi Pemerintah yang menyelenggarakan pendaftaran tanah diseluruh wilayah Republik Indonesia menurut pasal 5 yaitu: Badan Pertanahan Nasional (BPN), selanjudnya dalam pasal 6 ayat 1 di tegaskan dalam rangka penyelenggara pendaftaran tanah tersebut, di laksanakan oleh Kepala Kantor Pertanahan Kabupaten/Kota. Badan Pertanahan Nasional pada mulanya diatur dengan Keputusan Presiden Nomor 26 Tahun 1988, kemudian di tambah dengan Keputusan Presiden Nomor 154 Tahun1999, Kemudian di ubah dengan Keputusan Presiden Nomor 95 Tahun 2000, yang kemudian diubah dengan Peraturan Presiden Nomor 10 Tahun 2006, tentang Badan Pertanahan Nasional, kemudian diubah dengan Peraturan Presiden Nomor 63 Tahun 2013 tentang Badan Pertanahan Nasional (Boedi, 2012).

Pendaftaran tanah adalah rangkaian kegiatan yang di lakukan oleh pemerintah secara terus menerus, berkesinambungan dan teratur, meliputi pengumpulan, pengelolaan, 
pembukuan penyajian serta pemeliharaan data fisik dan data yuridis dalam bentuk peta dan daftar, mengenai bidang-bidang tanah dan satu-satuan rumah susun, termasuk pemberian sertifikat sebagai surat bukti hak bagi bidang-bidang tanah yang sudah ada hak nya dan hak milik atas satuan rumah susn serta hak-hak tertentu yang membebaninya (pasal 1 angka 1 PP Nomor 24 Tahun 1997). Hak atas tanah adalah hak sebagaimana yang di atur dalam pasal 16 Undang-undang Nomor 5 Tahun 1960 tentang Peraturan Dasar Pokok Agraria.Bidang tanah adalah bagian permukaan bumi yang merupakan satuan bidang yang terbatas. Pendaftaran tanah untuk pertama kali dapat di lakukan dengan cara sporadik adalah bagian pendaftaran tanah untuk pertama kali yang dilakukan atas permintaan pihak yang berkepentingan, mengenai satu atau beberapa objek pendaftaran tanah dalam wilayah atau bagian wilayah suatu desa/kelurahan secara individu atau masal.

Pelayanan publik adalah sebagai setiap kegiatan yang dilakukan oleh pemerintah terhadap sejumlah manusia yang memiliki setip kegiatan yang menguntungkan dalam suatu kumpulan atau kesatuan, dan penawaran kepuasan meskipun hasilnya tidak terikat pada suatu produk secara fisik. Keputusan menteri Pendayugunaan Aparatur Negara Nomor 63 Tahun 2003 sebagai berikut: pelayanan publik adalah segala kegiatan pelayanan yang dilakukan oleh penyelenggara pelayanan publik sebagai upaya pemenuhan kebutuhan penerima pelayanan maupun pelaksanaan ketentuan peraturan perundang-undangan (Ratminto dan Septiwinarsih, 2016).

Sebagai institusi pelayanan publik, Kementerian Agraria dan Tata Ruang/ Badan Pertanahan Nasional senantiasa berusaha meningkatkan kualitas pelayanan di bidang pertanahan, salah satunya dengan melaksanakan inovasi-inovasi layanan berbasis teknologi informasi dan

Dalam konteks administrasi bidang pertanahan, Kantor Pertanahan Kota Batam bertugas untuk mengelola dan mengembangkan administrasi pertanahan yang meliputi :

a. Pengaturan penggunaan, pengurusan, dan pemilikan tanah.

b. Pengurusan hak-hak tanah.

c. Dan lain-lain yang berkaitan dengan masalah pertanahan.

Pada dasarnya Kantor Pertanahan sebagai unit kerja Badan Pertanahan Nasional bertugas membantu Presiden dalam mengelola dan mengembangkan administrasi pertanahan. Inilah yang menguatkan Kantor Pertanahan sebagai satu-satunya instansi pemerintah yang 
mengurusi masalah pertanahan karena administrasi pertanahan itu adalah merupakan sebagian dari tugas-tugas pemerintah yang harus dilaksanakan secara baik dalam rangka menuju kesejahteraan rakyat Indonesia. Tercapainya jaminan kepastian hukum mengenai kepemilikan tanah yang meliputi kepastian pemiliknya, kepastian letak dan batas-batasnya, serta kepastian haknya diperlukan proses administrasi yang tepat. Semua bidang tanah yang didaftar harus dibukukan, kemudian diterbitkanlah sebuah sertipikat tanah. Bagi tanah hak dilaksanakan melalui konversi, sedangkan bagi tanah negara dilaksanankan melalui pemberian hak.

\section{METODE PENELITIAN}

Jenis penelitian yang di gunakan dalam penelitian ini adalah diskriftip kualitatif . Penelitian ini bertujuan untuk menggambarkan dan harus mampu menjelaskan secara tepat fenomena yang terjadi secara sistematis, aktual dan akurat sesuai dengan fakta yang ada dengan pengumpulan data, menjelaskan dan menganalisa secara objektif dalam arti hasi penelitian ini lebih menekankan pada gambaran kualitas pelayanan dalam pelaksanaan pendaftaran tanah pertama kali secara sporadik.

\section{PEMBAHASAN}

Kualitas pelayanana Kantor Pertanahan dalam Pendaftaran tanah secara sporadik adalah kegiatan pendaftaran tanah untuk pertama kali mengenai satu atau beberapa obyek pendaftaran tanah dalam wilayah atau bagian wilayah suatu desa/kelurahan secara individual atau pun massal. Kegiatan dari pelaksanaan pendafataran tanah pertama kali secara sporadik yaitu: pengumpulan dan pengelolaan data fisik dan pembuktian hak dan pembukuannya. Karakteristik suatu kulitas pelayanan yaitu: bukti fisik, kehandalan, daya tanggap, jaminan, dan empati.

\section{Bukti Fisik}

Bukti fisik merupakan kemampuan suatu perusahaan dalam menunjukkan eksistensinya kepada pihak eksternal atau masyarakat. Penampilan dan kemampuan sarana dan prasarana fisik perusahaan yang dapat diandalkan keadaan lingkungan sekitarnya merupakan bukti nyata dari pelayanan yang diberikan oleh pemberi jasa. Hai ini meliputi fasilitas fisik, seperti : Kebersihan dan kenyamanan, ruang tunggu, gedung, kelengkapan.

a. Kebersihan dan kenyamanan 
Dalam memberikan pelayanan pendaftaran tanah kepada masyarakat, kantor pertanahan Kota Batam mempunyai tujuan yang ingin di capai dalam hal kualitas pelayanan. Dimana berhasil atau tidaknya suatu pelayanan juga dinilai dari fasilitas gedung untuk suatu pelayanan. Hal ini sesuai dengan visi Kantor Pertanahan Kota Batam yaitu menjadi lembaga yang mampu mewujudkan tanah dan pertanahan untuk sebesar-besar kemakmuran rakyat, serta keadilan dan berkelanjutan sistem kemasyarakatan, kebangsaan dan kenegaraan Republik Indonesia.Fasiltas memang lebih di utamakan demi kelancaran suatu pelayanan.

Faktor lingkungan dalam kebijakan pelayanan yang di berikan kepada masyarakat, seperti di ketahui, lingkungan merupakan faktor yang penting dalam pelaksanaan pelayanan pendaftaran tanah. Jika lingkungan yang menjadi tempat pelayanan kesehatan buruk maka akan mempengaruhi proses pelayanan dan kesehatan masyarakat itu sendiri begitu pula sebaliknya. Namun kenyataanya masih ada masyarakat yang mengeluh tentang kebersihan di kantor pertanahan kota Batam.

Dalam memberikan pelayanan kepada pemohon atau masyarakatdi Kantor Pertanahan Kota Batam dilihat dari kebersihan dan kenyamanan sudah mulai bersih namun masih ada juga yang kurang bersih seperti di toilet, ini perlu di perhatikan dan di perbaiki demi kenyamanan. Kantor Pertanahan juga harus mampu menunjukkan eksistensinya kepada pihak eksternal atau masyarakat. Penampilan dan kemampuan sarana dan prasarana fisik perusahaan yang dapat diandalkan keadaan lingkungan sekitarnya merupakan bukti nyata dari pelayanan yang diberikan oleh pemberi jasa.

b. Ruang Tunggu

Dalam memberikan pelayanan pendaftaran tanah kepada pemasyarakatan, kantor pertanahan Kota Batam mempunyai tujuan yang ingin di capai dalam hal kualitas pelayanan. Dimana berhasil atau tidaknya suatu pelayanan juga dinilai dari fasilitas gedung untuk suatu pelayanan. Hal ini sesuai dengan visi Kantor Pertanahan Kota Batam yaitu menjadi lembaga yang mampu mewujudkan tanah dan pertanahan untuk sebesar-besar kemakmuran rakyat, serta keadilan dan berkelanjutan sistem kemasyarakatan, kebangsaan dan kenegaraan Republik Indonesia.

Fasilitas ruang tunggu di Kantor Pertanahan Kota Batam keadannya panas di karenakan AC di ruang tunggu rusak belum ada perbaikan dari Kantor Pertanahan Kota Batam kemudian adanya TV tidak di fungsikan untuk informasi-informasi penting.Keadaan 
ruang tunggu ruangannya minim kursi di ruang tunggu sedikit seangkan pemohon yang dating selalu ramai sehingga yang tidak dapat tempat duduk harus berdiri.Demi kelancaran pelayanan seharusnya di perhatikan dan di perbaiki oleh Kantor Pertanahan Kota Batam agar lebih baik dan lebih maksimal.

\section{c. Gedung}

Hasil observasi dilapangan diketahui bahwa gedung Kantor Pertanahan Kota Batam memang terletak dilokasi yang sangat strategis berada di tepi jalan, mudah dijangkau baik dengan kendaraan roda dua maupun roda empat. Sesuai dengan standar Kantor Pertanahan memiliki jarak terdekat dengan kecamatan sekupang dan dengan dinas kependudukan. Fasilitas fisik dan jenis jasa yang diberikan oleh Kantor Pertanahan Kota Batam memang sudah cukup baik. Fasilitas gedung yang ada di Kantor Pertanahan Kota Batam sudah bagus dengan adanya Kepala Kantor yang baru ini sudah banyak perubahan bahkan di gedung di bagian belakang sedang mengadakan pembangunan untuk dua lantai agar pelayanan lebih baik dan teratur.

d. Kelengkapan

Sarana prasarana merukapan salah satu penunjang suatu proses pelayanan pablik seperti halnya fasiltas perlengkapan untuk proses pelayanan sesuai dengan visi Kantor Pertanahan Kota Batam yaitu menjadi lembaga yang mampu mewujudkan tanah dan pertanahan untuk sebesar-besar kemakmuran rakyat, serta keadilan dan berkelanjutan sistem kemasyarakatan, kebangsaan dan kenegaraan Republik Indonesia.

Sarana prasarana adalah salah satu penunjang suatu proses pelayanan publik seperti halnya fasilitas perlengkapan untuk proses pelayanan Pelaksanaan Pendaftaran Tanah di Kantor Pertanahan Kota Batam. Fasilitas kelengkapan lainnya tersedianya kursi yang melancarakan suatu pelaksanaan dari pelayanan pendaftaran tanah pertama kali secara sporadik.

Sarana dan prasarana merupakan fasilitas sebagai pendukung kegiatan organisasi sangat dibutuhkan. Sarana yang memadai dapat memperlancar aktivitas organisasi, sebaliknya sarana yang tidak memadai dapat menghambat aktivitas organisasi.Sarana dan prasarana di Kantor Pertanahan Kota Batam merupakan faktor yang mempermudah pelayanan selain SDM. 
Dokumen pertanahan secara umum berbahan dasar kertas (paper base) dalam berbagai jenis dan ukuran.Dokumen tersebut merupakan alat bukti di pengadilan, sehingga keamanan tempat penyimpanan dokumen merupakan salah satu kebutuhan pokok bagi pelaksanaan tugas pertanahan.Sebagai institusi pelayanan publik, Kantor Pertanahan Kota Batam saat ini telah memiliki prasarana penunjang kegiatan cukup memadai yaitu sarana kegiatan lapangan (alat ukur dan perekam data lapangan), sarana alat pengolahan data yang berbasis teknologi informasi, sarana-sarana kerja maupun sarana mobilitas.Sarana dan prasarana dalam suatu organisasi merupakan alat bantu. Sarana dan prasarana tersebut membantu mempermudah penyelenggaraan pelayanan di Kantor Pertanahan Kota Batam.Kinerja Kantor Pertanahan Kota Batam juga dapat berjalan lancar jika didukung dengan sarana dan prasarana yang memadai dan dibutuhkan sesuai fungsi masing-masing.

Kantor Pertanahan Kota Batam memberikan kemudahan kepada pemohon yang merasa kurang paham degan persyaratan pendaftaran tanah namun kantor pertanahan memberikan stiker persyaratan pendaftaran tanah pertama kali di depan pintu masuk loket kemudian dengan adanya kursi sebagai kelengkapan pelayanan pendaftaran tanah dengan adanya kursi maka pemohon tidak perlu berdiri. Kelengkapan dalam pelayanan di Kantor Pertanahan Kota Batam memang tidak di ragukan lagi, di lihat bahwa kelengkapan dari Kantor Pertanahan Kota Batam sudah lengkap dengan adanya alat-alat dalam pelayanan maupun dari segi teknis.

Kemudian hal yangmelengkapi dari pelayanan pendaftaran tanah yaitu komputer yang dinamakan Land Office Compurization (LOC) atau Komputerisasi Kantor Pertanahan (KKP). Pemanfaatan perangkat keras komputer dan perangkat lunak aplikasi sistem komputerisasi pertanahan untuk membantu para pelaksana dan pejabat dalam melaksanakan seluruh tugas kantor pertanahan secara efektif, efisien dan terkendali dalam rangka peningkatan kinerja.

Dengan demikian Kantor Pertanahan Kota Batam sebagai instansi pelayanan publik telah memanfaatkan komputer yang dinamakan Land Office Compurization atau Komputerisasi Kantor Pertanahan. Pemanfaatan perangkat keras komputer dan perangkat lunak aplikasi sistem komputerisasi pertanahan dalam rangka untuk membantu para pelaksana dan pejabat dalam melaksanakan seluruh tugas Kantor Pertanahan secara efektif, efisien dan terkendali yang tentunya akan berdampak pada pelayanan masyarakat.

\section{Kehandalan}


Kualitas pelayanan dalam pelaksanaan pendaftaran tanah untuk pertama kali secara sporadik dalam kegiatannya di ukur dengan kehandalan karena kempuan untuk dalam memberikan pelayanan memberikan pelayanan dengan tepat janji, segera, akurat, ketepatan waktu, memberikan pelayanan yang maksimal. Maka dari itu perlu adanya suatu kemampuan pegawai dalam melaksanakan tugasnya.

a. Memberikan pelayanan yang akurat dan cepat

Dalam memberikan pelayanan perlu adanya suatu janji ketepatan waktu agar pelayanan yang diberikan menjadi maksimal. Kantor Pertanahan Kota Batam untuk sekarang dalam proses penyelesaiannya sudah sangat bagus bahkan sangat cepat yang prosesnya sekitar 3 bulan sekarang proses dari pendaftaran tanah sudah semakin cepat bahkan di tahun ini penyelesaian berkas pendaftaran 7 hari sudah selesai.

b. Pemberian pelayanan yang maksimal

Pemberikan pelayanan yang maksimal perlu adanya agar pelayanan yang diberikan menjadi baik demi kelancaran suatu pelayanan. Namun, kenyataanya masih ada pemohon yag merasa belum puas dengan yang di berikan. Kualitas pelayanan kantor pertanahan dalam pelaksanaan Pendaftaran Tanah di Kantor Pertanahan Kota Batam di lihat dari pemberian pelayanan yang maksimal masih kurang baik dengan pelayanan yang di berikan kepada pemohon. Dari hasil observasi dan wawancara, kualitas pelayanan pendaftaran tanah di Kantor Pertanahan Kota Batam di ukur dari kehandalan dilihat dari pemberian pelayanan yang akurat dan cepat itu sudah mulai bagus penyelesaian proses dari pendaftaran tanah sudah semakin cepat sudah ada perubahan namun di lihat dari pemberian pelayanan denagn maksimal masih ada keluhan dari pemohon bahwa pelayanan yag di berikan masih belum maksimal. Perlu adanya perbaikan agar pelayanan yang diberikan semakin baik.

\section{Daya Tanggap}

Daya tanggap adalah kerelaan untuk menolong custumers dan menyelenggarakan dengan iklas.Tanggap dalam memberikan informasi masalah atau keluhan dan tanggap dalam merespon permintaan masyarakat secara cepat dan tepat.Dalam melaksanakan tugasnya pegawai atau petugas bekerja sesuai SOP di mana petugas bekerja sesuai prosedur yang ada.Seorang pegawai harus bertanggung jawab dalam tugasnya seperti berkominikasi langsung dengan pemohon. Dalam memberikan informasi yang jelas akan mempermudah suatu pelayanan. Seperti apabila pemohon yang ingin menayakan tentang kejelasan dari yang 
di daftarnya misalnya dari waktu penyelesaiannya maka petugas di tuntut untuk menjelaskan dengan baik dan benar agar di pahami oleh masyarakatatau pemohon itu sendri.

Masih ada hal yang tanggap dari Kantor Pertanahan Kota Batam bahwa, Kantor tersebut mempermudahkan masyarakat yang ingin membuat sertifikat tanah namun tidak bisa datang ke Kantor Pertanahan Kota Batam karena faktor ekonomi, maka Kantor Pertanahan Kota Batam menjalankan program yang membantu masyarakat yang terkendalam atau membatu masyarakat di luar Pulau Batam. Dengan adanya program Layanan Rakyat Sertifikasi Tanah ( LARASITA) membantu masyarakat.

Model pelayanan larasita berbasis sistem aplikasi pelayanan LOC (Land Office Computerization) yang dilakukan secara mobile dengan memanfaatkan teknologi Wi-Fi, sehingga disebut LOC Mobile.Peralatan tersebut mampu melakukan transfer dan komunikasi data secara online ke server LOC yang ada di Kantor Pertanahan, sehingga apa yang terjadi di mobil Larasita akan terbaca di kantor pertanahan, begitu juga sebaliknya. Dengan demikian maka sistem pelayanan pertanahan pada Larasita sama dengan sistem pelayanan yang dilakukan di Kantor Pertanahan, baik mengenai prosedur, syarat dan biaya. Mekanisme pelayanan pelayanan dengan menggunakan Larasita sama halnya dengan mengurus sendiri di Kantor Pertanahan, hanya saja Larasita dapat mendatangi lokasi.

Kantor Pertanahan Kota Batam sudah melayani pemohon pendaftaran tanah dengan tanggap dan mempermudah dari pelayanan maupun mepermudah dari proses kesulitan dari pemohon. Masih ada hal yang tanggap dari Kantor Pertanahan Kota Batam bahwa, Kantor tersebut mempermudahkan masyarakat yang ingin membuat sertifikat tanah namun tidak bisa datang ke Kantor Pertanahan Kota Batam karena faktor ekonomi, maka Kantor Pertanahan Kota Batam menjalankan program yang membantu masyarakat yang terkendal atau membatu masyarakat di luar Pulau Batam. Dengan adanya program Layanan Rakyat Sertifikasi Tanah ( LARASITA) sangat membantu masyarakat.

\section{Jaminan}

Dalam memberikan pelayanan perlu adanya pengetahuan, kesopanan, kemapuan dan sifat yang dapat dipercaya dalam memberikan pelayanan kepada masyarakat. Kantor Pertanahan Kota Batam menunjukkan bahwa tenaga pegawai Kantor Pertanahan Kota Batam sudah memiliki latar beakang pendidikan yang memadai antara lain pendidikan Sarjana, kemudian banyaknya jumlah satpam yang mengaman di sekitar Kantor Pertanahan Kota 
Batam. Jumlah pegawai di Kantor Pertanahan sudah memadai, tidak ada kekurangan tenaga, komunikasi dengan pemohon juga baik, pelayanan yang diberikan juga sudah sesuai dengan Standar Operasional Prosedur (SOP).Dengan demikian pemohon merasa menjadi aman dan nyaman dalam menerima pelayanan di Kantor Pertanahan Kota Batam.

Berdasarkan hasil penelitian di ketahui bahwa pelayanan di Kantor Pertanahan Kota Batam sudah cukup bagus tetapi masih ada yang merasa belum puas dengan pelayanan di Kantor Pertanahan Kota Batam karena masih ada pegawai yang lebih mementingkan urusan mereka sendri dari pada pemohon.Masih ada keluhan dari pemohon atau masyarakat.Perlu adanya koreksi kembali tentang pelayanan untuk kenyamanan pemohon atau masyarakat saat melakukan pelayanan di Kantor Pertanahan Kota Batam.

\section{Empati}

Indikator yang satu ini yaitu memberikan suatu pelayanan yang baik, selalu mementingkan atau mengutamakan kepentingan pemohon pendaftaran tanah. Kemampuan dalam memberikan perhatian yang tulus dan bersifat individual yang diberikan kepada para pelanggan dengan berupaya memahami keinginan pemhon seperti: perhatian secara individual, jam operasi, pemahaman kebutuhan, pemahan kebutuhan secara spesifik, membangun minat dan kesesuaian jam kerja yang telah di tentukan.

Dari hasil wawancara dengan masyarakat dapat di ketahui masalah kesediaan petugas dalam melayani masyarakat sudah baik dengan banyaknya tanggapan yang menyatakan cukup baik. Pemberian pelayanan kesediaan pegawai dalam memberikan informasi terhadap masyarakat yang membutuhkan pelayanan akan dapat memperbaiki cara pelayanan di mata masayrakat. Sehingga dalam menciptakan pelayanan prima masyarakat perlu di dukung dengan adanya pegawai yang berempati dalam mebantu kebutuhan masyarakat yang di butuhkan informasi.

\section{KESIMPULAN DAN SARAN}

\section{Kesimpulan}

Berdasarkan hasil penelitian dari pembahasan yang telah di lakukan, dapat di tarik kesimpulan bahwa Kualitas Pelayanan Kantor Pertanahan dalam Pelaksanaan Pendaftaran Tanah Pertama Kali Secara Sporadik dalam kegiatannya di ukur dengan karakteristik pelayanan yang ada yaitu: Bukti Fisik, Kehandalan, Daya Tanggap, Jaminan, Empati.. 


\section{a. Bukti Fisik}

Dari hasil wawancara di atas di ketahui bahwa untuk fasilitas kebersihan dan kenyamanan di Kantor Pertanahan Kota Batam sudah sangat baik di bandingkan dari tahun yang dulu-dulu walaupun masih ada dari pemohon yang mengeluh tentang kebersihan di WC, fasilitas di rung tunggu yang ada sudah baik, cuma masih terbatasnya kursi di ruang tunggu dan keadaan AC yang rusak sehingga di ruang tunggu tersebut panas. Namun pemohon masih mengatakan kurang baik untuk masalah antrian, yang terlalu lama.Fasilitas di bagian gedung sudah baik dan bagus.Fasilitas perlengkapan pun masyarakat banyak merasakan puas dengan fasilitas yang di berikan kepada pemohon, namun masih ada perlu perbaikan agar pelayanan pendaftaran tanah di Kantor Pertanahan Kota Batam lebih baik.

b. Kehandalan

Kualitas pelayanan kantor pertanahan dalam pelaksanaan Pendaftaran Tanah di Kantor Pertanahan Kota Batam di lihat dari pemberian pelayanan yang maksimal masih kurang baik dengan pelayanan yang di berikan kepada pemohon. Dari hasil observasi dan wawancara, kualitas pelayanan pendaftaran tanah di Kantor Pertanahan Kota Batam di ukur dari kehandalan dilihat dari pemberian pelayanan yang akurat dan cepat itu sudah mulai bagus penyelesaian proses dari pendaftaran tanah sudah semakin cepat sudah ada perubahan namun di lihat dari pemberian pelayanan denagn maksimal masih ada keluhan dari pemohon bahwa pelayanan yag di berikan masih belum maksimal. Perlu adanya perbaikan agar pelayanan yang diberikan semakin baik.

c. Daya Tanggap

Kantor Pertanahan Kota Batam Sudah memberikan pelayanan yang tanggap.Pegawai Kantor pertanahan Kota Batam mmembantu permasalahan pemohon atau masyarakat dengan tanggap.Program layana rakyat sertifikasi tanah juga membantu masyarakat yang ingin mendaftar pendaftaran tanah.

d. Jaminan

Dari hasil wawancara di atas di ketahui bahwa pelayanan di Kantor Pertanahan Kota Batam sudah cukup bagus tetapi masih ada yang merasa belum puas dengan pelayanan di Kantor Pertanahan Kota Batam karena masih ada pegawai yang lebih mementingkan urusan mereka sendri dari pada pemohon.Masih ada keluhan dari pemohon atau masyarakat.Perlu 
adanya koreksi kembali tentang pelayanan untuk kenyamanan pemohon atau masyarakat saat melakukan pelayanan di Kantor Pertanahan Kota Batam.

e. Empati

Dari hasil wawancara dengan masyarakat dapat di ketahui masalah kesediaan petugas dalam melayani masyarakat sudah baik dengan banyaknya tanggapan yang menyatakan cukup baik. Pemberian pelayanan kesediaan pegawai dalam memberikan informasi terhadap masyarakat yang membutuhkan pelayanan akan dapat memperbaiki cara pelayanan di mata masayrakat. Sehingga dalam menciptakan pelayanan prima masyarakat perlu di dukung dengan adanya pegawai yang berempati dalam mebantu kebutuhan masyarakat yang di butuhkan informasi.

\section{Saran}

Berdasarkan hasil penelitian dan kesimpulan di buat oleh penulis, maka penulis memberikan bebrapa rekomendasi sebagai berikut:

a.) Perlu adanya pelatihan mengenai pelayanan agar para petugas mengerti dan memahami dan dapat melaksanakan tugas dan tanggung jawab mereka secara optimal.

b.) Perlu adanya perbaikan dan tambahan terhadap fasilitas-fasilitas di Kantor Pertahanan Kota Batam.

\section{REFERENSI}

Achmad, Ali, 2002. Hukum Pertanahan, Pemberian Hak Atas Tanah Negara, Sertifikat dan Permasalahan. Jakarta: Prestasi Pustaka

Brotosoelarni, Soelarman, 1997. Aspek Teknis Yuridis Pendaftaran Tanah Berasarkan PP Nomor 24 Tahun 1997, Yogyakarta,

Fea, Oryza, Radhite, Dyara, 2016. Buku Pintar Mengurus Sertifikat Tanah Rumah \& Perizinannya, Yogyakarta. Buku Pintar.

Harsono, Boedi, 2012. Hukum Agraria Indonesia.Jakarta. Katalog Dalam Terbitan(TDP)

Lupiyoadi.Rambat dan Hamdan i. A. ,2006. Manajemen Pemasaran Jasa, Edisi ke2.Jakarta: Salemba

Ratminto \& Atik Septi Winarsih, 2015.manajemen Pelayanan.Jogjakarta: pustaka pelajar 
Meri Enita Puspita Sari:Kualitas Pelayanan Kantor Pertanahan Dalam...

Sahnan, 2016.Hukum Agraria Indonesia,malang. Setara Press Kelompok Intrans Publishing

Sugiyono. 2014. Metode Penelitian Kuantitatif Kualitatif dan R \& . Bandung.Alfabeta

Thamrin, Husni, 2013. Hukum Pelayanan Publik di Indonesia, Yogyakarta. Aswaja

Wahanisa, Rofi, 2008, Buku Ajar Pendaftaran Tanah. Semarang: Universita Negeri Semarang.

Undang-Undang Republik Indonesia Nomor 24 Tahun 1997 Tentang Pendaftaran Tanah

Undang-undang Republik Indinesia Nomor 5 Tahun 1960. tentang Peraturan Dasar PokokPokok Agraria (UUPA).

Peraturan Menteri Negara Agraria/ Kepala Badan Pertanahan Nasional Nomor 3 Tahun 1997Tentang Ketentuan Pelaksanaan Peraturan Pemerintah Nomor 24 Tahun 1997 Tentang Pendaftaran Tanah.

Tunjungsari, Hamni, Eka. 2007. Analisis Kualitas Pelayanan Sertifikat Tanah Secara Konveksi Sporadik Di Kantor Pertanahan Kabupaten Bayuwangi. 